\title{
Phospholipids of the liver in children suffering from protein-calorie undernutrition
}

\author{
BY K. K. CHATTERJEE AND K. L. MUKHERJEE \\ Institute of Child Health, Calcutta $\mathbf{1} 7$, India \\ (Received 30 March 1967-Accepted 18 October 1967 )
}

\begin{abstract}
I. Thirty-nine children suffering from protein-calorie undernutrition were classified into nineteen with kwashiorkor, twelve with marasmus and eight with nutritional oedema according to history, physical findings and laboratory investigations. Liver biopsy samples from these patients were extracted with lipid solvents and the phospholipids were fractionated into phosphatidylcholine, ethanolamine and serine, and sphingomyelin.

2. The total liver phospholipids were found to be reduced in kwashiorkor and the reduction was mainly in the phosphatidyl ethanolamine fraction. The decrease in phosphatidyl ethanolamine was probably due to an observed reduction in free serine content. The ethanolamine phosphatase activity of the liver was found to be high in kwashiorkor.
\end{abstract}

Children, aged from 6 months to 4 years and suffering from severe and prolonged protein-calorie undernutrition can be clinically grouped into three syndromes of kwashiorkor, marasmus and nutritional oedema (marasmic kwashiorkor) (Mukherjee, I 967). The liver undergoes characteristic changes in lipid composition in all three states of protein-calorie undernutrition (H. Pal \& K. L. Mukherjee, unpublished, I967). It is enlarged and fatty in kwashiorkor (Waterlow, 1948), small and not fatty in marasmus and slightly fatty in nutritional oedema. The increase in the concentration of fat in the liver in kwashiorkor and nutritional oedema can be accounted for by triglycerides (U. Ganguli, H. Pal \& K. L. Mukherjee, unpublished, I967). The concentration of the phospholipids is not increased; on the contrary there may be a slight reduction in the total phospholipid content of the liver in protein-calorie undernutrition. The individual phospholipids of the liver, however, have not been extensively studied in these children. The present paper deals with some investigations on the total phospholipid content and fractionation of the phospholipids of the liver in children suffering from protein-calorie undernutrition. It appears that there is a reduction in the total phospholipid content in kwashiorkor; the reduction is mainly in the phosphatidyl ethanolamine fraction and is probably due to non-availability of serine for biosynthesis of ethanolamine.

\section{EXPERIMENTAL}

Thirty-nine children suffering from protein-calorie undernutrition were grouped into those with kwashiorkor (nineteen), marasmus (twelve) and nutritional oedema (eight), according to history, physical examination and laboratory findings (Mukherjee, I967). Briefly, the distinguishing characteristics of kwashiorkor were prolonged subsistence on diets which were moderately poor in calories but very poor in proteins, loss of weight mostly involving muscle tissues, moderate preservation of subcutaneous fat, oedema, enlarged liver, hair dyspigmentation, crazy pavement dermatosis, mental apathy, hypoproteinaemia and hepatic steatosis. Marasmus was characterized by con- 
sumption of diets poor in both calories and protein, marked loss of weight involving all the organs of the body including the subcutaneous fat and the liver, absence of oedema, crazy pavement dermatosis, mental apathy, hypoproteinaemia and hepatic steatosis. The chief characteristics of nutritional oedema were history of dietetic deprivation in both calories and protein, loss of weight, absence of subcutaneous fat and crazy pavement dermatosis, presence of oedema, hypoproteinaemia and moderate hepatic steatosis. Needle biopsy of the liver (Nelson, 1954) by a Vim Silverman needle was performed by the transthoracic route on all children in the morning after an overnight fast of $8 \mathrm{~h}$. They were gradually put on a diet containing $150-200 \mathrm{cal}$ and 4-5 $\mathrm{g}$ protein/kg body-weight daily. The oedematous children lost oedema within $4^{-I I}$ days and gained about $30 \%$ of their initial body-weight in $\mathrm{I}^{\cdot} 5^{-2}$ months on such a diet. The liver biopsy was repeated on all children at this time before discharge. Liver samples were obtained from two children who were undergoing exploratory laparotomy for surgical conditions and were treated as normal controls.

The biopsy specimens ranged from 6 to $35 \mathrm{mg}$. In children with kwashiorkor and nutritional oedema the biopsy was easily done and $15-35 \mathrm{mg}$ tissue could easily be obtained. But it was not so easy in marasmus and only 6-18 $\mathrm{mg}$ tissue could be obtained. Within 2-3 min after removal, the tissue was homogenized in a glass homogenizer with $\mathrm{I} \mathrm{ml}$ chloroform-methanol $(2: \mathrm{I}, \mathrm{v} / \mathrm{v})$ in the cold. The homogenate was transferred with washing $(0.5 \mathrm{ml})$ to a centrifuge tube and shaken at room temperature in a microid flask shaker for $5 \mathrm{~h}$. It was centrifuged and the supernatant layer was transferred to a second centrifuge tube; the residue was re-extracted for $0.5 \mathrm{~h}$ with $0.5 \mathrm{ml}$ fresh chloroform-methanol $(2: \mathrm{r}, \mathrm{v} / \mathrm{v})$ and centrifuged; the supernatant layer was transferred to the second tube. The process was repeated twice. The total supernatant fraction $(3-4 \mathrm{ml})$ was dried under nitrogen at $45^{\circ} ;$ I $\mathrm{ml} \mathrm{light} \mathrm{petroleum}$ (b.p. $60-80^{\circ}$ ) was added to the dried residue and the lipids were extracted by slight warming. The lipid extract was centrifuged, decanted into tared flasks and evaporated under nitrogen; the flasks were kept under reduced pressure in a desiccator overnight and the difference in the weight was taken to represent the total lipid content.

The lipids were dissolved in $\mathrm{I} \mathrm{ml}$ chloroform and $100 \mu \mathrm{l}$ were taken in a microKjeldahl flask and digested with $\mathrm{I} \mathrm{ml} 60 \% \mathrm{HClO}_{4}$ and a drop of conc. $\mathrm{HNO}_{3}$ for $0.5 \mathrm{~h}$. The perchloric acid was boiled off almost to dryness and the residue was dissolved in $2 \mathrm{ml}$ water to which was added $\mathrm{I} \mathrm{ml} 0.25 \%(\mathrm{w} / \mathrm{v})$ ammonium molybdate and $\mathrm{I} \mathrm{ml}$ I0 $\%(\mathrm{w} / \mathrm{v})$ ascorbic acid. The mixture was incubated at $37^{\circ}$ for $\mathrm{I} \mathrm{h}$, made up to $5 \mathrm{ml}$ and the optical density was measured at $65^{\circ} \mathrm{nm}$. A microKjeldahl flask containing only chloroform and another containing $4 \mu \mathrm{g}$ inorganic phosphorus (as $\mathrm{KH}_{2} \mathrm{PO}_{4}$ ) were treated in the same way. The method of inorganic phosphorus determination was a modification of that of Lowry \& Lopez (1946).

The individual phospholipids were separated by chromatography on filter paper impregnated with silicic acid. The solvent system was di-isobutyl ketone:acetic acid: water (40:25:5, v/v) as described by Marinetti, Albrecht, Ford \& Stotz (1959). A control strip with an extract from normal liver was run side by side. The positions of the individual phospholipids were marked on the control strip by their fluorescence under ultraviolet light with Rhodamine- $6 \mathrm{G}$ and the corresponding spots were cut 
out from the unknown strips. The actual identification of the major phospholipids was carried out by comparison of the $R_{F}$ values with authentic samples of dimyristyl phosphatidyl choline and dimyristyl phosphatidyl ethanolamine kindly donated by Professor Erich Baer. The choline-containing phospholipids were also identified with the phosphomolybdic acid reagent (Levine \& Chargaff, I95 I). Ethanolamine- and serine-containing phosphatides were detected with ninhydrin. The individual phospholipids were eluted from the strips with warm methanolic $\mathrm{HCl}$. The methanolic hydrochloric acid was evaporated off and the phospholipids were digested and measured according to the method above.

Towards the later part of this work, thin-layer chromatography was used to separate the phospholipids by the method of Skipski, Peterson \& Barclay (1964) using chloroform, methanol, acetic acid and water $(25: 15: 4: 2, \mathrm{v} / \mathrm{v})$ as the developing solvent, but Kiesel gel G (Merck) was used to make the thin-layer plates. The positions of the spots were identified with iodine vapour, and the spots were identified and eluted and the phosphorus contents were determined according to the methods described above.

Free serine was determined in the cold trichloroacetic acid extract of the liver tissue by a modification of the method of Frisell, Meech \& Mackenzie (1954). The extract was taken in a tear-drop flask and adjusted with $5 \mathrm{~N}-\mathrm{NaOH}$ to the phenolphthalein end-point ( $\mathrm{pH} 8-9$ ). After neutralization, $\mathrm{I} \mathrm{ml} 25 \%$ sodium arsenite was added and the contents were oxidized by adding $0.5 \mathrm{M}-\mathrm{HIO}_{4}$ until just acid to methyl red $\left(\mathrm{pH}_{5}-6\right)$. The addition of excess periodic acid was always avoided. Four ml water were added and almost the whole contents of the flask were distilled under a low flame. The condenser of the microdistillation apparatus was cooled by continuous circulation of ice-cold water. The distillate containing dissolved formaldehyde was collected under $0.5 \mathrm{ml}$ water. Seven $\mathrm{ml}$ distillate were collected and $0.5 \mathrm{ml}$ was left in the flask. The distillate was transferred to a $12 \mathrm{ml}$ Pyrex tube and $0.5 \mathrm{ml}$ chromotropic acid reagent (I,8-dihydroxynaphthalene-3,6-disulphonic acid) was added. After mixing, the test tubes were kept in an ice container and $4 \mathrm{ml}$ conc. $\mathrm{H}_{2} \mathrm{SO}_{4}$ were added very slowly. The test tubes were then kept in a boiling water bath for $0.5 \mathrm{~h}$ and the intensity of the pink colour was determined at $570 \mathrm{~nm}$ after cooling. A blank tube containing $0.5 \mathrm{ml}$ $0 \cdot 154 \mathrm{M}-\mathrm{KCl}$ and a standard tube containing $0.4 \mu \mathrm{M}$-serine were treated in the same manner as the unknown, beginning from the trichloroacetic acid extraction.

Ethanolamine phosphate was prepared according to the method of Colowick \& Kaplan (1957). The optimum conditions for the estimation of liver ethanolamine phosphatase were standardized on rat kidney. The optimum $\mathrm{pH}$ was found to be between 8.4 and 9.4 . The optimum substrate concentration for 2-10 mg tissue was found to be $5 \times 10^{-4} \mathrm{M}$. The inorganic phosphate liberated during the first $15 \mathrm{~min}$ was found to be linear. In assay system with human liver we used veronal buffer $\mathrm{pH} 8.5$, $0.0 \mathrm{M}, \mathrm{r} .0 \mathrm{ml}$; ethanolamine phosphate $0.75 \mu \mathrm{M}$ in $0.3 \mathrm{ml}$ and liver homogenate (in $0.22 \mathrm{M}$-sucrose) $0.2 \mathrm{ml}$. The system was incubated at $37^{\circ}$ for $\mathrm{I} 5 \mathrm{~min}$, after which it was placed in an ice-cold bath and $\mathrm{r} \cdot 5 \mathrm{ml} 10 \%$ trichloroacetic acid were added. To the blank the acid was added immediately and without any incubation. Inorganic phosphorus was determined in portions of the centrifuged supernatant liquid and the activity was calculated as $\mu \mathrm{g}$ phosphorus liberated by $100 \mathrm{mg}$ tissue at $37^{\circ}$ in $15 \mathrm{~min}$. 


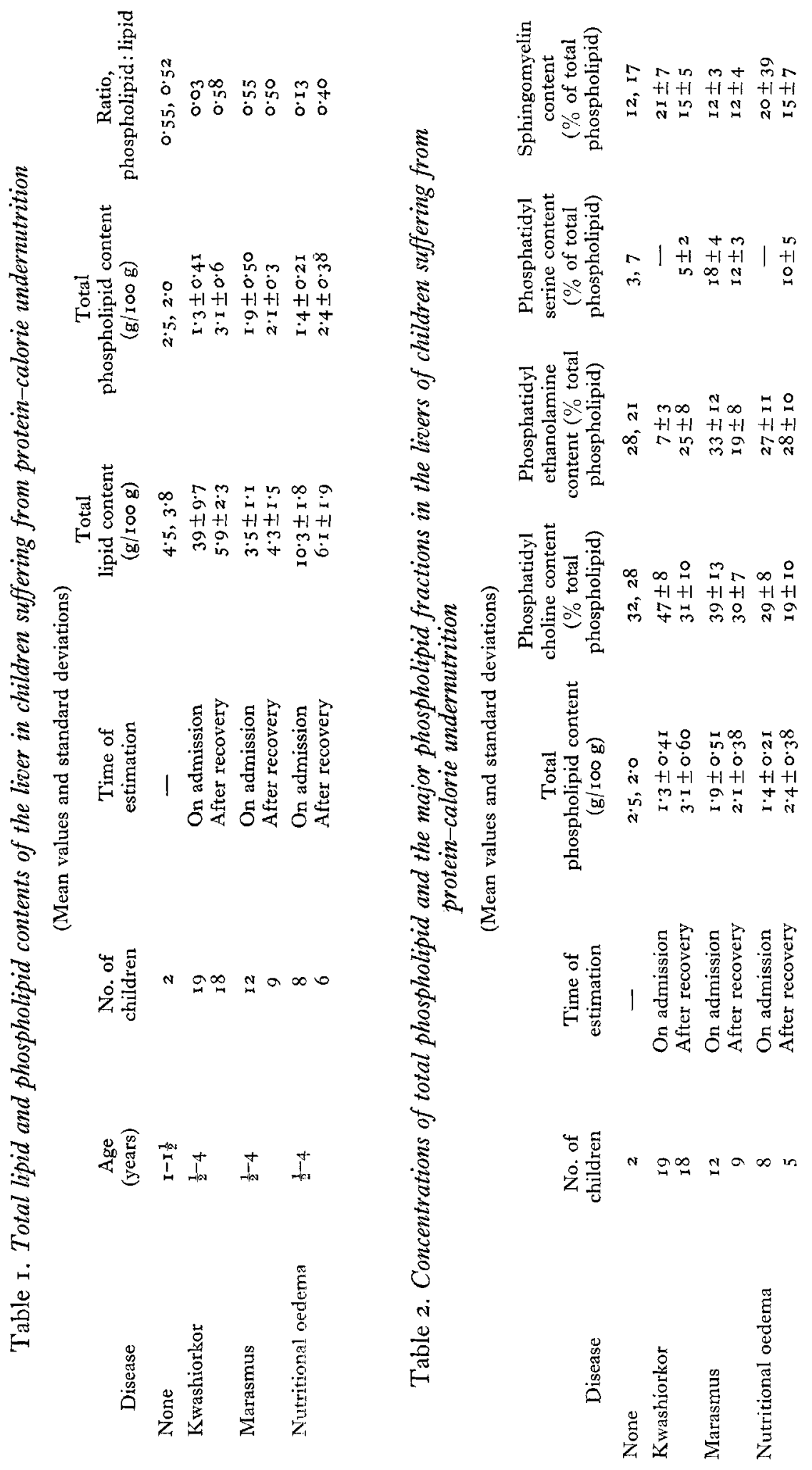




\section{RESULTS}

\section{Total lipid and phospholipid content of the liver}

This particular method of extraction of lipids was used because of some concomitant studies on liver glycogen which appeared to be preserved in the residue. The standardization was carried out on rat livers; the mean lipid content obtained by this method was $5^{\cdot 6} \pm \mathrm{I} \cdot 9 \mathrm{~g} / \mathrm{I} 00 \mathrm{~g}$ (sixteen observations) as compared with $5 \cdot 4 \pm 2 \cdot \mathrm{I}$ (ten observations) obtained by the method of Folch, Ascoli, Lees, Meath \& LeBaron (1951). The extraction was therefore taken to be quantitative. Table I shows the total lipid and phospholipid contents of the liver in protein-calorie undernutrition in children.

The total lipid content of the liver in kwashiorkor was nine times that of normal livers and eleven times that of marasmic livers. The phospholipid content, however, was lower than normal in the livers of children with kwashiorkor. As a result, the phospholipids which normally accounted for more than half of the total liver lipids accounted for only $3 \%$ of the total liver lipids in kwashiorkor. In marasmus, the total lipid content as well as the phospholipid content of the liver remained at more or less normal levels. In nutritional oedema the total lipid contents were about

Table 3. Free serine contents ( $\mu$ moles/100 mg wet weight) of the liver in children suffering from protein-calorie undernutrition on admission and after recovery

$\begin{array}{lcccc}\text { Disease } & \begin{array}{c}\text { No. of } \\ \text { children }\end{array} & \text { On admission } & \text { After I month } & \text { After } 2 \text { months } \\ \text { Kwashiorkor } & 9 & \mathrm{I} \cdot 20 \pm 0.3 \mathrm{I} & 2.87 \pm 0.60 & 3.56 \pm 0.50 \\ \text { Marasmus } & 4 & 2 \cdot 9 \mathrm{I} \pm 0.73 & - & 2.86 \pm 0.9 \mathrm{I} \\ \text { Nutritional } & 4 & 3.43 \pm \mathrm{I} \cdot 03 & - & 3 . \mathrm{I} 5 \pm 0.69 \\ \text { oedema } & & & & \end{array}$

twice the normal values but the phospholipid contents were lower than normal. On clinical recovery of the patients (i.e. after the patients had gained more than $30 \%$ of their initial oedema-free body-weight), both the total lipid and phospholipid contents of the liver reverted to nearly normal values. In some patients with kwashiorkor a number of biopsies were undertaken serially during the course of treatment. Such liver biopsies showed progressive diminution of fat contents and a more gradual increase of phospholipid contents.

In children admitted with kwashiorkor the relative as well as the absolute amounts of phosphatidyl ethanolamine in the liver were lower than normal (column 6, Table 2). In some of the children the amounts were too low to be detectable by the method described. The phosphatidyl choline and sphingomyelin contents were not very much different from the normal values or from the values obtained after recovery. Phosphatidyl serine could not be readily separated from phosphatidyl inositol by thin-layer chromatography. With paper impregnated with silicic acid, however, phosphatidyl serine could be better separated. As a method, thin-layer chromatography is much easier to perform than chromatography on paper impregnated with silicic acid. In marasmus, both the total phospholipid contents and the individual phospholipid 
fractions were similar to those in normal livers. In nutritional oedema the phosphatidyl ethanolamine contents were not lower than normal.

The primary step in the biosynthesis of phosphatidyl ethanolamine involves decarboxylation of serine to ethanolamine, most probably at the level of free serine rather than at the level of $o$-phosphoryl serine. It was therefore thought advisable to estimate the free serine content of the liver in protein-calorie undernutrition of children. Results are shown in Table 3 . The free serine contents of the liver were low in the liver of children with kwashiorkor but increased progressively during recovery to almost three times the initial values. On the other hand, the free serine contents of the liver in children with marasmus and nutritional oedema were the same on admission as before discharge and similar to the values obtained in kwashiorkor after recovery. It was found that the other hydroxy amino acids such as threonine and hydroxylysine did not materially interfere with the chromogen in equimolar quantities.

Table 4. Ethanolamine phosphatase activity of the liver in children suffering from protein-calorie undernutrition

$\begin{array}{cccc}\text { Disease } & \begin{array}{c}\text { Time of } \\ \text { rneasurement }\end{array} & \begin{array}{c}\text { No. of } \\ \text { observations }\end{array} & \begin{array}{c}\text { Ethanolamine } \\ \text { phosphatase } \\ \text { activity }(\mu \mathrm{g}\end{array} \\ \text { phosphorus } / \mathrm{I} 00 \mathrm{mg} \\ \text { tissue per I5 min) }\end{array}$

Ethanolamine formed from serine is converted by ethanolamine phosphokinase into ethanolamine phosphate which according to the Kennedy pathway (Kennedy \& Weiss, 1956) combines with CTP to form CDP-ethanolamine. An alternative pathway of metabolism of ethanolamine phosphate is dephosphorylation to ethanolamine. Since liver alkaline phosphatase was found to be high in kwashiorkor (Mukherjee \& Sarkar, 1958), it was decided to study ethanolamine phosphatase activity of the liver in protein-calorie undernutrition in children. Results are shown in Table 4.

The ethanolamine phosphatase activity of the liver in kwashiorkor on admission was found to be three times that found after recovery. In three children with marasmus the enzyme activity on admission was a little higher than that found in one patient after recovery.

\section{DISCUSSION}

In kwashiorkor the accumulation of excess fat involves mainly triglycerides which constitute more than $95 \%$ of the total fat. The phospholipid contents, however, were slightly diminished and, as a result, the normal ratio of phospholipids to lipid was. reduced to a very low level. Macdonald (1960) also found low ratios of phospholipid to lipid in the livers of persons dying from malnutrition. The maintenance of a constant amount of phospholipids in the tissues during starvation has been known for a long time since Terroine (1920) introduced the term 'element constant' in his 
pioneering studies. Probably the phospholipids constitute structural elements of the various unit membranes (Robertson, 1959) and therefore the total amounts can fall to an irreducible minimum if the structural integrity is to be maintained.

The reduced phosphatidyl ethanolamine content of the liver is probably due to non-availability of adequate amounts of free serine. But it is surprising to find that the phosphatidyl choline content is not diminished in spite of such low amounts of phosphatidyl ethanolamine. Biosynthesis of choline involves methylation of ethanolamine (duVigneaud, Chandlar, Simmonds, Moyer \& Cohn, 1946). If the synthesis of ethanolamine is low because of low serine content, this should have resulted in reduced choline biosynthesis and hence low phosphatidyl choline.

The adaptation of tissue to altered environment is very complex. Thus, although most of the enzyme activities are reduced in protein calorie undernutrition, some are spared (Mukherjee \& Sarkar, 1958; Waterlow, Cravioto \& Stephen, I960). The high ethanolamine phosphatase activity in kwashiorkor probably results in a direct synthesis of choline from the little amount of ethanolamine that can be formed from the reduced free serine content. In that sense it may be presumed that phosphatidyl choline is, perhaps, biologically more important than phosphatidyl ethanolamine.

\section{REFERENCES}

Colowick, S. P. \& Kaplan, N. O. (editors) (1957). Meth. Enzym. 3, 357.

du Vigneaud, V., Chandlar, J. P., Simmonds, S., Moyer, A. W. \& Cohn, M. (1946). F. biol. Chem. r64, 603.

Folch, J., Ascoli, I., Lees, M., Meath, J. A. \& LeBaron, F. N. (195I). F. biol. Chem. I91, 833.

Frisell, W. R., Meech, L. A., \& Mackenzie C. G. (1954). J. biol. Chem. 207, 709.

Kennedy, E. P. \& Weiss, S. B. (1956). F. biol. Chem. 222, 193.

Levine, C. \& Chargaff, C. (195 I). $尹$. biol. Chem. I92, 455 .

Lowry, O. H. \& Lopez, J. A. (1946). F. biol. Chem. 162, 42 I.

Macdonald, I. ( ( 960 ). Metabolism, 9, 836.

Marinetti, G. V., Albrecht, M., Ford, T. \& Stotz, E. (1959). Biochim. biophys. Acta 36, 4.

Mukherjee, K. L. (1967). Archs Dis. Childh. 42, 647.

Mukherjee, K. L. \& Sarkar, N. K. (1958). Br. F. Nutr. I2, I.

Nelson, R. S. (1954). Am. F. med. Sci. 227 , 152.

Robertson, J. D. (1959). Biochim. Soc. Symp. no. 16, p. 43.

Skipski, V. P., Peterson, R. F. \& Barclay, M. (I 964). Biochem Y. 9o, 374.

Terroine, E. F. (1920). Ann. nat. Zool. Paris 1o, Sér. 4, p. I.

Waterlow, J. C. (1948). Spec. Rep. Ser. med. Res. Coun. no. 263.

Waterlow, J. C., Cravioto, J. \& Stephen, J. M. L. (1960). Adv. Protein Chem. 15, I31. 